\title{
The Production of Set-Type-Bio-Yoghurt with Commercial Probiotic Culture
}

\author{
L. Yilmaz-Ersan and E. Kurdal
}

\begin{abstract}
In this study, the yoghurt and bio-yoghurt were produced using different commercial probiotic combinations of S. thermophilus, L. bulgaricus, L. acidophilus, Bifidobacterium ssp., $L$. lactis and $L$. case $i$. The samples were analyzed for microbiological, physico-chemical and sensorial properties at a 5-day interval during storage. Culture combinations and storage time significantly influenced some properties of the samples. While titratable acidity and lactic acid (\%) increased, syneresis, pH, lactose and acetaldehyde decreased during storage. Changes in fat, ash, protein contents of yoghurt samples during storage period were not remarkable. Viable probiotic bacterial counts in all bio-yogurts were above $10^{7} \mathrm{cfu}$ $\mathrm{g}^{-1}$ at the end of storage except for $\mathrm{C}$ sample. Considering sensory properties of bio-yoghurt samples, the highest overall acceptabilities by panelists were obtained for $\mathrm{C}$ sample.
\end{abstract}

Index Terms-Bio-yoghurt, probiotic culture.

\section{INTRODUCTION}

The beneficial effects of foods with added nutritive value on human health are being highly promoted by health professionals. This awareness has led to an increased market demand particularly within children and other high-risk individuals for functional dairy products containing probiotic bacteria as it's positive effect on health has come to the forefront of the public's attention.

The probiotics, live non-pathogenic microorganisms, are defined as microbial cell supplement which exert positive impact on the health of the host when ingested alive in sufficient amount. The main health benefits include improved the intestinal microbial balance, lactose metabolisation, stimulation of the digestive and immune system, reduction of blood cholesterol level, prevention against urinary infections, cardiovascular diseases, diarrhea, osteoporosis, as well as anti-mutagenic and anti-carcinogenic properties [1]-[7].

The most prominent probiotic bacteria associated with food products worldwide are Lactobacillus and Bifidobacterium species, which are common but nondominant members of the indigenous microflora of the human gastro-intestinal tract. The health benefits are not only dependent on the choice of microorganism with specific therapeutic properties, but it is also essential that these live microorganisms are consumed in sufficient quantities to exhibit the desired beneficial health effects. Several authors have suggested that the minimum necessary concentration at the moment of ingestion is $10^{6}-10^{9}$ viable cells $\mathrm{g}^{-1}$ in the

Manuscript received November 20, 2013; revised March 5, 2014.

Lutfiye Yilmaz-Ersan is with the Department of Food Engineering, Faculty of Agriculture, Uludag University, Bursa, Turkey (e-mail: lutfiyey@uludag.edu.tr). final product, and this is named as "the therapeutic minimum" [8]-[13].

Fermented dairy foods are the ideal food matrix for probiotics, which promotes growth and enhances viability of these organisms. Of these foods, yoghurt is the most popular, and provides higher levels of protein, carbohydrate, calcium and certain B vitamins than milk. In general, yoghurt is produced by lactic acid fermentation of pasteurized milk using Streptococcus thermophilus and Lactobacillus delbrueckii subsp. bulgaricus, so called yoghurt starter culture. These bacteria are not bile acid resistant and do not survive in the passage of intestinal tract. Thus, recently, probiotic bacteria such as L. acidophilus, Bifidobacterium ssp., L. casei and L. rhamnosus incorporated into yoghurt starter culture due to their bile-resistant properties and beneficial health effects. The resulting product, called as "yoghurt-like products", "probiotic" or "bio-yoghurts", are becoming more popular due to the ability of excellent health effects of probiotic bacteria [14]-[17].

The objective of this work was to determine the effects of the starter cultures on microbiological, physico-chemical and sensorial properties of the set-type bio-yoghurt produced using commercial blends of starter cultures ( $S$. thermophilus, L. bulgaricus, L. acidophilus, Bifidobacterium ssp., L. lactis and $L$. casei). The bio-yoghurt samples were evaluated during storage of 25 days at refrigerated temperature $\left(4 \pm 1^{\circ} \mathrm{C}\right)$.

\begin{tabular}{|c|c|c|c|}
\hline Code & Starter Cultures & $\begin{array}{c}\text { Incubation } \\
\text { temperature } \\
\left({ }^{\circ} \mathbf{C}\right)^{*} \\
\end{array}$ & $\begin{array}{c}\text { Incubation } \\
\text { time } \\
\text { (h)* }\end{array}$ \\
\hline $\begin{array}{c}\text { A } \\
\text { (Control) }\end{array}$ & $\begin{array}{l}\text { Streptococcus thermophilus } \\
\text { Lactobacillus bulgaricus }\end{array}$ & 42 & 3 \\
\hline B & \begin{tabular}{|l|} 
Streptococcus thermophilus \\
Lactobacillus acidophilus \\
Bifidobacterium ssp.
\end{tabular} & 42 & 5.5 \\
\hline $\mathrm{C}$ & $\begin{array}{l}\text { Streptococcus thermophilus } \\
\text { Lactobacillus acidophilus } \\
\text { Lactobacillus lactis } \\
\text { Bifidobacterium ssp. } \\
\end{array}$ & 42 & 7 \\
\hline D & $\begin{array}{l}\text { Lactobacillus acidophilus } \\
\text { Bifidobacterium lactis }\end{array}$ & 40 & 6.5 \\
\hline $\mathrm{E}$ & $\begin{array}{l}\text { Lactobacillus acidophilus } \\
\text { Bifidobacterium lactis } \\
\text { Lactobacillus casei }\end{array}$ & 40 & 6.5 \\
\hline
\end{tabular}

*Recommendations of Starter Culture Suppliers

\section{MATERIALS AND METHODS}

\section{A. Materials and Methods}

For manufacturing of yoghurt samples, raw bovine milk was obtained from a local dairy plant (EKER Dairy Co., Bursa, Turkey). Skimmed milk powder was purchased from 
Pınar Dairy Co., Izmir, Turkey

Sample code, the microorganisms used in commercial starter cultures and incubation conditions were described in Table I.

\section{B. Manufacture of Experimental Bio-Yoghurt}

Control yoghurt and bio-yoghurts were manufactured using five commercial starter cultures. The milk was tempered to $45^{\circ} \mathrm{C}$, fortified with $3 \%$ (w/v) nonfat dry milk, heated to $90^{\circ} \mathrm{C}$ for $10 \mathrm{~min}$ and cooled to incubation temperature. The starter cultures were added and incubation was carried out according to the recommendations of the manufacturer until $\mathrm{pH}$ 4.6. The yogurts, produced in three replicates, were kept at room temperature $\left(20^{\circ} \mathrm{C}\right)$ for $30 \mathrm{~min}$., stored at $4 \pm 1^{\circ} \mathrm{C}$ and assessed $1,5,10,15,20$ and 25 days of storage.

\section{Microbiological Analysis}

The culture growth and viability were evaluated taking 1 $\mathrm{mL}$ of each sample, decimally diluting it and plating on media described in Table II on 1, 5, 10, 15, 20 and 25 days of storage. The suitability of media for the selective growth of $S$. thermophilus, $L$. bulgaricus, L. acidophilus, Bifidobacterium ssp., L. lactis and L. casei was evaluated as described in Table II.

TABLE II: CUlture MEDIA FOR SELECTIVE GROWTH ACCORDING TO THE LITERATURE

\begin{tabular}{|c|c|c|c|c|c|}
\hline Culture & Culture Media & Incubation & $\begin{array}{c}\text { Temperature } \\
\left({ }^{\circ} \mathrm{C}\right)\end{array}$ & $\begin{array}{c}\text { Time } \\
\text { (h) }\end{array}$ & References \\
\hline S. thermophilus & M17-Agar & Aerobic & 37 & 72 & $\begin{array}{c}\text { Dave and Shah [18]- } \\
\text { Donkor et al..[19] }\end{array}$ \\
\hline L. bulgaricus & $\begin{array}{l}\text { MRS agar } \\
(\mathrm{pH} \mathrm{5.2)}\end{array}$ & Anaerobic & 43 & 72 & $\begin{array}{c}\text { Tharmaraj and Shah } \\
{[20]}\end{array}$ \\
\hline L. acidophilus & Bile-MRS agar & Aerobic & 37 & 72 & $\begin{array}{c}\text { Vinderola and } \\
\text { Reinheimer [21] }\end{array}$ \\
\hline Bifidobacterium ssp. & LP-MR agar & Anaerobic & 37 & 72 & $\begin{array}{c}\text { Vinderola and } \\
\text { Reinheimer [21] - } \\
\text { Lapierre et al. [22] }\end{array}$ \\
\hline L. lactis & Elliker Agar & Anaerobic & 42 & 72 & $\begin{array}{c}\text { Zimbro and Power } \\
{[23]}\end{array}$ \\
\hline L. casei & Vancomycin-MRS agar & Anaerobic & 37 & 72 & $\begin{array}{c}\text { Tharmaraj and Shah } \\
{[20]}\end{array}$ \\
\hline
\end{tabular}

\section{Physico-Chemical Analysis}

Different physico-chemical parameters such as moisture, ash, fat, protein and lactose in all prepared bio-yoghurt samples were estimated by the method described in A.O.A.C. [24]. The $\mathrm{pH}$ values of the samples were measured using digital pH meter (Analyzer model 315i/SET, WTW, Germany). The titratable acidity (LA \%) was determined according to A.O.A.C. [25] during storage. Syneresis was estimated using a drainage test according to Atamer and Sezgin [26]. The quantification of lactic acid [27] and acetaldehyde [28] contents were determined spectrophotometric ally.

\section{E. Sensory Evaluation}

Ten panelists, selected depending on their availability and willingness to participate in the study, from staff of Department of Food Engineering, Uludag University, evaluated the sensory properties of the bio-yoghurt samples, after preliminary training sessions. Samples in three digit random number coded plastic cups were provided to panelists. The panelists were asked to note any defects or undesirable characteristics. Sensory evaluations were applied during the storage process using a five-point score system (5 excellent, 1 unacceptable).

\section{F. Statistical Analysis}

A factorial experiment was designed with the product type and the storage time as the main factors. Analysis of variance (ANOVA) using $99 \%$ confidence intervals was run on each of the analyzed variables. Analysis of variance with mean separations using the LSD multiple range test as the level of significant difference was used to determine the effect of starter culture differences and storage time on physico-chemical, microbiological and sensorial properties. Different letters were used to label values with statistically significant differences among them. All analyses were performed using the Minitab for Windows (Version 10) Statistical Software Package (Minitab Inc., State College, PA).

\section{RESUlTS AND DISCUSSION}

\section{A. Incubation Period}

Incubation of the yoghurt samples was ceased when the $\mathrm{pH}$ of the samples reached 4.6. The results obtained showed that the incubation periods of experimental yoghurts differed significantly $(P<0.01$, data not shown). While the sample A (control yoghurt) reached the target $\mathrm{pH}$ within $3 \mathrm{~h}$, the incubation times of the $\mathrm{B}, \mathrm{C}, \mathrm{D}$ and $\mathrm{E}$, containing probiotic bacteria combination, were $4.30,6.30,8$ and $10 \mathrm{~h}$, respectively. The incubation period of the samples was found to be dependent on the type or concentration of the probiotic cultures used.

\section{B. Microbiological Characteristics of the Experimental Bio-Yoghurts}

The changes in the viable counts of yoghurt and probiotic bacteria during storage are presented Table III. $S$. thermophilus counts of control and bio-yoghurt samples were effected significantly by culture combination type $(P<0.01)$. The highest $S$. thermophilus counts were found in sample $\mathrm{C}$ (as $8.72 \log _{10} \mathrm{cfu} \mathrm{g}^{-1}$ ), where the lowest were for control yoghurt (A) with $8.10 \log _{10} \mathrm{cfu} \mathrm{g}^{-1}$. For the reason 
that, L. bulgaricus was used only in control yoghurt, the effect of storage time over L. bulgaricus counts, which was found significant $(P<0.01)$. L. bulgaricus counts decreased throughout the storage time, the highest counts were on 1 st day (as $8.42 \log _{10} \mathrm{cfu} \mathrm{g}^{-1}$ ) whereas the lowest values were on 25th day (as $7.55 \log _{10} \mathrm{cfu} \mathrm{g}^{-1}$ ). The highest L. acidophilus counts of bio-yoghurts were determined in E (as $7.89 \log _{10}$ $\mathrm{cfu} \mathrm{g}^{-1}$ ), whilst the lowest values were in $\mathrm{C}$ (as $6.10 \log _{10} \mathrm{cfu}$ $\left.\mathrm{g}^{-1}\right)$. Among produced samples, the highest Bifidobacterium ssp. counts were in E (as $7.90 \log _{10} \mathrm{cfu} \mathrm{g}^{-1}$ ), whereas sample $\mathrm{B}$ displayed the lowest value (as $6.13 \log _{10} \mathrm{cfu} \mathrm{g}^{-1}$ ). L. lactis, since being found only in probiotic culture combination $\mathrm{C}$, analyzed statistically with respect to storage time, that displayed significant differences on counts $(P<0.01)$. $L$. lactis counts throughout storage time varied from $9.29 \log _{10}$ $\mathrm{cfu} \mathrm{g}^{-1}$ to $8.54 \log _{10} \mathrm{cfu} \mathrm{g}^{-1}$. Dave and Shah [29], Vinderola $e t$ al. [30] and Gustaw et al. [31] reported that counts of probiotic strains showed a decrease over storage time. Nevertheless, for all bio-yoghurts the probiotic populations were approximately $10^{6} \mathrm{cfu} \mathrm{g}^{-1}$ at the end of 25-day-storage. Recommendations for potential to exert the health-promoting effects the therapeutic minimum is quite variable. In general, the food industry applies the recommended level of $10^{6} \mathrm{cfu}$ $\mathrm{g}^{-1}$ at the time of consumption for probiotic bacteria to have the expected health effects [8]-[10]. According to the results of present study, all probiotic strains grew well and exhibited satisfactory viability levels after storage. The strains selected, acidity, storage temperature, oxygen content, $\mathrm{pH}$ and hydrogen peroxide due to bacterial metabolism, inoculation level, fermentation time, post-acidification and food matrix may be the major factors affecting the viability of probiotic microorganisms during manufacture and storage of fermented products [29], [30].

TABLE III: The Changes of Viable Bacteria Counts of SAmples During Storage (LOG CFU G ${ }^{-1}$ )

\begin{tabular}{|c|c|c|c|c|c|c|}
\hline Bacteria & Days of Storage & $\mathbf{A}$ & B & C & D & $\mathbf{E}$ \\
\hline \multirow{6}{*}{ S. thermophilus } & 1 & $8.51^{\mathrm{cA}}$ & $9.23^{\mathrm{bA}}$ & $9.31^{\mathrm{aA}}$ & - & - \\
\hline & 5 & $8.36^{\mathrm{cB}}$ & $8.88^{\mathrm{bB}}$ & $9.14^{\mathrm{aB}}$ & - & - \\
\hline & 10 & $8.23^{\mathrm{cC}}$ & $8.70^{\mathrm{bC}}$ & $8.81^{\mathrm{aC}}$ & - & - \\
\hline & 15 & $8.15^{\mathrm{cD}}$ & $8.65^{\mathrm{bD}}$ & $8.76^{\mathrm{aD}}$ & - & - \\
\hline & 20 & $7.80^{\mathrm{cE}}$ & $8.57^{\mathrm{bE}}$ & $8.73^{\mathrm{aE}}$ & - & - \\
\hline & 25 & $7.81^{\mathrm{cF}}$ & $8.39^{\mathrm{aF}}$ & $8.21^{\mathrm{bF}}$ & - & - \\
\hline \multirow{6}{*}{ L. bulgaricus } & 1 & $8.42^{\mathrm{A}}$ & - & - & - & - \\
\hline & 5 & $8.21^{\mathrm{A}}$ & - & - & - & - \\
\hline & 10 & $8.09^{\mathrm{A}}$ & - & - & - & - \\
\hline & 15 & $7.71^{\mathrm{A}}$ & - & - & - & - \\
\hline & 20 & $7.69^{\mathrm{A}}$ & - & - & - & - \\
\hline & 25 & $7.55^{\mathrm{A}}$ & - & - & - & - \\
\hline \multirow{6}{*}{ L. acidophilus } & 1 & - & $7.50^{\mathrm{cA}}$ & $7.17^{\mathrm{dA}}$ & $8.31^{\mathrm{bA}}$ & $8.43^{\mathrm{aA}}$ \\
\hline & 5 & - & $7.37^{\mathrm{bB}}$ & $6.88^{\mathrm{cB}}$ & $8.14^{\mathrm{aB}}$ & $8.14^{\mathrm{aB}}$ \\
\hline & 10 & - & $7.29^{\mathrm{bC}}$ & $6.55^{\mathrm{CC}}$ & $7.91^{\mathrm{aC}}$ & $7.96^{\mathrm{aC}}$ \\
\hline & 15 & - & $7.20^{\mathrm{CD}}$ & $6.04^{\mathrm{dD}}$ & $7.84^{\mathrm{bD}}$ & $7.93^{\mathrm{aD}}$ \\
\hline & 20 & - & $7.16^{\mathrm{CE}}$ & $5.45^{\mathrm{dE}}$ & $7.69^{\mathrm{bE}}$ & $7.88^{\mathrm{aE}}$ \\
\hline & 25 & - & $7.08^{\mathrm{bF}}$ & $5.30^{\mathrm{cF}}$ & $7.59^{\mathrm{aF}}$ & $7.54^{\mathrm{aF}}$ \\
\hline \multirow{6}{*}{ Bifidobacterium ssp. } & 1 & - & $7.01^{\mathrm{dA}}$ & $7.07^{\mathrm{cA}}$ & $8.50^{\mathrm{aA}}$ & $8.48^{\mathrm{bA}}$ \\
\hline & 5 & - & $6.45^{\mathrm{cB}}$ & $6.47^{\mathrm{CB}}$ & $7.93^{\mathrm{bB}}$ & $8.32^{\mathrm{aB}}$ \\
\hline & 10 & - & $6.05^{\mathrm{dC}}$ & $5.80^{\mathrm{cC}}$ & $7.77^{\mathrm{bC}}$ & $7.93^{\mathrm{aC}}$ \\
\hline & 15 & - & $5.96^{\mathrm{CD}}$ & $5.70^{\mathrm{dD}}$ & $7.60^{\mathrm{bD}}$ & $7.95^{\mathrm{aD}}$ \\
\hline & 20 & - & $5.74^{\mathrm{CE}}$ & $5.57^{\mathrm{dE}}$ & $7.44^{\mathrm{bE}}$ & $7.80^{\mathrm{aE}}$ \\
\hline & 25 & - & $5.66^{\mathrm{cF}}$ & $5.56^{\mathrm{dF}}$ & $7.16^{\mathrm{bF}}$ & $7.59^{\mathrm{aF}}$ \\
\hline \multirow{6}{*}{ L. lactis } & 1 & - & - & $9.29^{\mathrm{A}}$ & - & - \\
\hline & 5 & - & - & $9.00^{\mathrm{ABC}}$ & - & - \\
\hline & 10 & - & - & $8.77^{\mathrm{ABC}}$ & - & - \\
\hline & 15 & - & - & $8.70^{\mathrm{ABC}}$ & - & - \\
\hline & 20 & - & - & $8.62^{\mathrm{ABC}}$ & - & - \\
\hline & 25 & - & - & $8.54^{\mathrm{BC}}$ & - & - \\
\hline \multirow{6}{*}{ L. casei } & 1 & - & - & - & - & $8.07^{\mathrm{A}}$ \\
\hline & 5 & - & - & - & - & $7.81^{\mathrm{A}}$ \\
\hline & 10 & - & - & - & - & $7.61^{\mathrm{A}}$ \\
\hline & 15 & - & - & - & - & $7.55^{\mathrm{A}}$ \\
\hline & 20 & - & - & - & - & $7.46^{\mathrm{A}}$ \\
\hline & 25 & - & - & - & - & $7.33^{A}$ \\
\hline
\end{tabular}

a,b Different superscript lowercase letters denote significant differences $(P<0.01)$ between different samples

A,B Different superscripts capital letters denote significant differences $(P<0.01)$ between different times of storage

\section{Physico-Chemical Properties of the Experimental Bio- Yoghurts}

The chemical composition of cow milk used for the production of yogurt and bio-yogurt fell within the following averages: titratable acidity $0.15 \%$ (LA), $\mathrm{pH} 6.62$, total solids $12.66 \%$, fat $3.80 \%$ and protein $3.17 \%$.

The changes of some physico-chemical properties of yoghurt and bio-yoghurts during storage are presented Table IV. As it shows, the average $\mathrm{pH}$ values for all samples ranged from 4.60 to 4.10 during the storage. The highest $\mathrm{pH}$ value was found in $\mathrm{D}$ (as 4.43), and the lowest $\mathrm{pH}$ value was 4.24 for control (A). A gradual and consistent decrease in $\mathrm{pH}$ was noted significantly during 25 -day-storage $(P<0.01)$, but did not fall below $\mathrm{pH} 4.0$, which is generally considered detrimental to the survival of probiotic bacteria [29]. Whilst 
in control yoghurt only lactic acid is produced, lactic and acetic acids are produced by $L$. acidophilus and Bifidobacteria in bio-yoghurt. However, the post acidification, development of acidity during shelf life of yoghurt because of the conversion of lactose to lactic acid, was higher in control yoghurt compared to bio-yoghurts. Singh et al. [32], Ozer et al., [33] and Ranathunga and Rathnayaka [34] reported that the enzyme activity of starter bacteria used in bio-yoghurt production resulted in significant decrease in $\mathrm{pH}$ during storage.

TABLE IV: Changes of Physico-Chemical Properties of SAMPLES During STORAGE

\begin{tabular}{|c|c|c|c|c|c|c|}
\hline $\begin{array}{c}\text { Physico-chemical } \\
\text { Properties }\end{array}$ & $\begin{array}{l}\text { Days of } \\
\text { Storage }\end{array}$ & A & B & $\mathbf{C}$ & D & $\mathbf{E}$ \\
\hline \multirow{6}{*}{ pH } & 1 & $4.45^{\mathrm{bA}}$ & $4.48^{\mathrm{bA}}$ & $4.47^{\mathrm{bA}}$ & $4.60^{\mathrm{aA}}$ & $4.41^{\mathrm{cA}}$ \\
\hline & 5 & $4.36^{\mathrm{cB}}$ & $4.44^{\mathrm{bB}}$ & $4.43^{\mathrm{bB}}$ & $4.53^{\mathrm{aB}}$ & $4.39^{\mathrm{dA}}$ \\
\hline & 10 & $4.25^{\mathrm{cC}}$ & $4.34^{\mathrm{bC}}$ & $4.34^{\mathrm{bC}}$ & $4.40^{\mathrm{aC}}$ & $4.32^{\mathrm{bB}}$ \\
\hline & 15 & $4.20^{\mathrm{dD}}$ & $4.34^{\mathrm{bC}}$ & $4.34^{\mathrm{bC}}$ & $4.39^{\mathrm{aC}}$ & $4.31^{\mathrm{cB}}$ \\
\hline & 20 & $4.16^{\mathrm{cE}}$ & $4.30^{\mathrm{aD}}$ & $4.30^{\mathrm{aD}}$ & $4.31^{\mathrm{aD}}$ & $4.24^{\mathrm{bC}}$ \\
\hline & 25 & $4.10^{\mathrm{dF}}$ & $4.26^{\mathrm{bE}}$ & $4.25^{\mathrm{bE}}$ & $4.31^{\mathrm{aD}}$ & $4.14^{\mathrm{CD}}$ \\
\hline \multirow{6}{*}{$\begin{array}{c}\text { Titratable Acidity } \\
\text { (LA\%) }\end{array}$} & 1 & $1.58^{\mathrm{aC}}$ & $1.25^{\mathrm{cD}}$ & $1.41^{\mathrm{bD}}$ & $1.19^{\mathrm{dC}}$ & $1.19^{\mathrm{dE}}$ \\
\hline & 5 & $1.68^{\mathrm{aB}}$ & $1.43^{\mathrm{bC}}$ & $1.47^{\mathrm{bC}}$ & $1.28^{\mathrm{dB}}$ & $1.38^{\mathrm{cC}}$ \\
\hline & 10 & $1.74^{\mathrm{aAB}}$ & $1.53^{\mathrm{bB}}$ & $1.51^{\mathrm{bB}}$ & $1.34^{\mathrm{cA}}$ & $1.34^{\mathrm{CD}}$ \\
\hline & 15 & $1.79^{\mathrm{aA}}$ & $1.54^{\mathrm{bB}}$ & $1.51^{\mathrm{bB}}$ & $1.36^{\mathrm{cA}}$ & $1.58^{\mathrm{bB}}$ \\
\hline & 20 & $1.81^{\mathrm{aA}}$ & $1.56^{\mathrm{cB}}$ & $1.57^{\mathrm{cA}}$ & $1.38^{\mathrm{dA}}$ & $1.68^{\mathrm{bA}}$ \\
\hline & 25 & $1.83^{\mathrm{aA}}$ & $1.61^{\mathrm{cA}}$ & $1.57^{\mathrm{dA}}$ & $1.39^{\mathrm{eA}}$ & $1.69^{\mathrm{bA}}$ \\
\hline $\begin{array}{l}\text { Syneresis } \\
\left(\mathbf{m L ~} 25 \mathrm{~g}^{-1}\right)\end{array}$ & $\begin{array}{c}1 \\
5 \\
10 \\
15 \\
20 \\
25\end{array}$ & $\begin{array}{l}4.95^{\mathrm{bD}} \\
5.06^{\mathrm{dC}} \\
5.10^{\mathrm{dC}} \\
5.11^{\mathrm{eC}} \\
5.92^{\mathrm{cB}} \\
6.20^{\mathrm{cA}}\end{array}$ & $\begin{array}{l}4.65^{\mathrm{dC}} \\
5.13^{\mathrm{cB}} \\
5.17^{\mathrm{cB}} \\
5.70^{\mathrm{bA}} \\
5.76^{\mathrm{dA}} \\
5.80^{\mathrm{cA}}\end{array}$ & $\begin{array}{l}4.65^{\mathrm{dF}} \\
4.87^{\mathrm{eE}} \\
5.11^{\mathrm{dD}} \\
5.38^{\mathrm{dC}} \\
5.45^{\mathrm{eB}} \\
6.23^{\mathrm{cA}}\end{array}$ & $\begin{array}{l}5.66^{\mathrm{aD}} \\
6.13^{\mathrm{aC}} \\
6.24^{\mathrm{aB}} \\
6.25^{\mathrm{aB}} \\
6.33^{\mathrm{aB}} \\
7.86^{\mathrm{aA}}\end{array}$ & $\begin{array}{l}4.90^{\mathrm{cF}} \\
5.18^{\mathrm{bE}} \\
5.39^{\mathrm{bD}} \\
5.57^{\mathrm{cC}} \\
6.08^{\mathrm{bB}} \\
6.92^{\mathrm{bA}}\end{array}$ \\
\hline \multirow{6}{*}{ Lactose (\%) } & 1 & $4.42^{\mathrm{eA}}$ & $4.98^{\mathrm{bA}}$ & $4.60^{\mathrm{dA}}$ & $5.17^{\mathrm{aA}}$ & $4.85^{\mathrm{cA}}$ \\
\hline & 5 & $4.27^{\mathrm{eB}}$ & $4.66^{\mathrm{bB}}$ & $4.51^{\mathrm{dB}}$ & $4.81^{\mathrm{aB}}$ & $4.60^{\mathrm{CB}}$ \\
\hline & 10 & $4.12^{\mathrm{dC}}$ & $4.53^{\mathrm{bC}}$ & $4.46^{\mathrm{cC}}$ & $4.66^{\mathrm{aC}}$ & $4.52^{\mathrm{bC}}$ \\
\hline & 15 & $4.12^{\mathrm{dC}}$ & $4.45^{\mathrm{cD}}$ & $4.43^{\mathrm{cC}}$ & $4.66^{\mathrm{aC}}$ & $4.52^{\mathrm{bC}}$ \\
\hline & 20 & $4.02^{\mathrm{eE}}$ & $4.35^{\mathrm{cE}}$ & $4.41^{\mathrm{bC}}$ & $4.58^{\mathrm{aD}}$ & $4.31^{\mathrm{dD}}$ \\
\hline & 25 & $4.07^{\mathrm{dD}}$ & $4.30^{\mathrm{bF}}$ & $4.30^{\mathrm{bD}}$ & $4.56^{\mathrm{aD}}$ & $4.26^{\mathrm{CE}}$ \\
\hline \multirow{6}{*}{$\begin{array}{l}\text { Lactic Acid } \\
\left(\mathrm{mg} 100 \mathrm{~g}^{-1}\right)\end{array}$} & 1 & $1.06^{\mathrm{aD}}$ & $0.73^{\mathrm{bD}}$ & $0.77^{\mathrm{bE}}$ & $0.75^{\mathrm{bE}}$ & $0.70^{\mathrm{CD}}$ \\
\hline & 5 & $1.15^{\mathrm{aC}}$ & $0.85^{\mathrm{cC}}$ & $0.94^{\mathrm{bD}}$ & $0.87^{\mathrm{cD}}$ & $0.73^{\mathrm{dD}}$ \\
\hline & 10 & $1.18^{\mathrm{aC}}$ & $0.92^{\mathrm{cB}}$ & $0.97^{\mathrm{bC}}$ & $0.94^{\mathrm{cC}}$ & $0.78^{\mathrm{dC}}$ \\
\hline & 15 & $1.22^{\mathrm{aAB}}$ & $0.96^{\mathrm{bA}}$ & $0.99^{\mathrm{bC}}$ & $0.99^{\mathrm{bB}}$ & $0.80^{\mathrm{cB}}$ \\
\hline & 20 & $1.23^{\mathrm{aAB}}$ & $0.96^{\mathrm{cA}}$ & $1.04^{\mathrm{bB}}$ & $1.03^{\mathrm{bA}}$ & $0.96^{\mathrm{cA}}$ \\
\hline & 25 & $1.25^{\mathrm{aA}}$ & $0.97^{\mathrm{cA}}$ & $1.08^{\mathrm{bA}}$ & $1.04^{\mathrm{bA}}$ & $1.02^{\mathrm{bA}}$ \\
\hline \multirow{6}{*}{$\begin{array}{l}\text { Acetaldehyde } \\
\text { (ppm) }\end{array}$} & 1 & $20.66^{\mathrm{bA}}$ & $14.67^{\mathrm{dA}}$ & $27.48^{\mathrm{aA}}$ & $20.81^{\mathrm{bA}}$ & $18.39^{\mathrm{cA}}$ \\
\hline & 5 & $16.08^{\mathrm{cB}}$ & $14.11^{\mathrm{dA}}$ & $21.76^{\mathrm{aB}}$ & $16.26^{\mathrm{cB}}$ & $17.31^{\mathrm{bA}}$ \\
\hline & 10 & $14.06^{\mathrm{bC}}$ & $13.57^{\mathrm{bAB}}$ & $18.30^{\mathrm{aC}}$ & $11.17^{\mathrm{cC}}$ & $13.19^{\mathrm{bB}}$ \\
\hline & 15 & $13.58^{\mathrm{bC}}$ & $13.29^{\mathrm{bAB}}$ & $17.94^{\mathrm{aC}}$ & $10.60^{\mathrm{cC}}$ & $11.56^{\mathrm{cC}}$ \\
\hline & 20 & $13.40^{\mathrm{bC}}$ & $12.96^{\mathrm{bC}}$ & $15.03^{\mathrm{aD}}$ & $10.56^{\mathrm{cC}}$ & $10.97^{\mathrm{cC}}$ \\
\hline & 25 & $12.91^{\mathrm{bD}}$ & $12.74^{\mathrm{bC}}$ & $14.54^{\mathrm{aD}}$ & $10.10^{\mathrm{cC}}$ & $10.01^{\mathrm{cC}}$ \\
\hline
\end{tabular}

a,b Different superscript lowercase letters denote significant differences $(P<0.01)$ between different bio-yoghurt samples

A,B Different superscripts capital letters denote significant differences $(P<0.01)$ between different times of storage

Titratable acidity is a very important factor, which affects the shelf life and the acceptability of fermented dairy products [35]. The titratable acidity rate of samples displayed significant differences due to product type and storage time $(P<0.01)$. The titratable acidity of control and bio-yoghurts varied from 1.19 to $1.83 \%$ throughout storage time. In contrast to $\mathrm{pH}$, the acidity of samples showed significant increase $(P<0.01)$ during storage due to acid formation. Since $L$. bulgaricus is the main bacteria responsible for acid production, control sample had the highest acidity at the beginning and at the end of the storage period. The lowest acidity (1.39) was observed in the sample $\mathrm{D}$ at the end of the storage period. The level of acidity in bioyogurts was found to be lower than control yogurt. These results were in agreement with Singh et al. [32], Ranathunga and Rathnayaka [34], Vahicic and Hruskar [36], Guler-Akin and Akin [37], and Ozer et al. [38]. It appears that the composition of starter culture, fermentation temperature and storage period could influence the overall level of acidity and $\mathrm{pH}$ of stored yoghurt samples [32].
Syneresis is generally defined as separation of aqueous phase from continuous phase or gel network, which is an undesirable property in fermented milk products [17]. The highest syneresis at the end of the storage was determined in sample D, whereas the lowest value was obtained in sample C. Because of differentiations in metabolic activities of starter cultures, product type and storage time were significant on syneresis being in agreement with Panesar and Shinde [39] $(P<0.01)$. Besides, the acidity of the yogurts can be a further contributing factor, since higher acidity is known to stimulate syneresis in yogurt [40], [41].

The main carbohydrate in dairy and dairy products is lactose so called "milk sugar". The use of different culture combinations resulted in significant differences over product type and storage time in terms of lactose values $(P<0.01)$. Due to the production yield of lactic acid, the decrease in lactose content of bio-yoghurt samples during storage was determined to be culture dependent. These findings were in accordance with the observations of Sady et al. [42] and Bano et al. [43]. 
Lactic acid is suggested to be one of the major compounds of yogurt flavor [44]. The lactic acid values of yoghurt samples displayed significant differences due to product type and storage time $(P<0.01)$. A noticeable increase in lactic acid concentration was observed for all the bio-yoghurts throughout the storage period. The concentrations varied from 0.97 to $1.25 \mathrm{mg} 100 \mathrm{~g}^{-1}$. These results were in agreement with that obtained by Dave and Shah [29], who they reported a similar pattern of increase in parallel to titratable acidity.

Acetaldehyde is mainly responsible for the typical aroma of yogurt. In samples, the highest acetaldehyde value was 27.48 ppm in sample $C$, whereas the lowest was in sample D with $13.81 \mathrm{ppm}$. Therefore the differences in acetaldehyde contents could be the result of inoculum level and probiotic bacteria used, as in lactobacilli species the activity of alcohol dehydrogenase, which catalyzes the formation of acetaldehyde from threonine, is species-dependent. These results could be attributed to the fact that the counts of the total lactic acid bacteria in sample $\mathrm{C}$ were higher than those of other samples. The acetaldehyde content seemed to decrease during storage; the highest value being $27.48 \mathrm{ppm}$ for the 1st day and the lowest being $10.01 \mathrm{ppm}$ on 25 th day. The decrease in acetaldehyde levels can be related to the hydrolysis by microbial enzymes to form other substances, such as ethanol. In addition, carbonyl compound production capacity of bifidobacteria and lactobacilli are limited when compared to the yoghurt starter bacteria [38]-[40]. The panelists mentioned a mild flavor in bio-yoghurts. Similar results were also reported by Guler-Akin and Akin [37] and Bonczar et al. [45].

No significant differences were observed in fat, ash and protein contents of the yoghurt samples $(P>0.05$; data not shown).

\section{Sensory Evaluations of the Experimental Bio-Yoghurts}

The popularity of yogurt depends mainly on its sensory characteristics, of which are characterized as the microbial factors, processing parameters, source of milk and the additives used. The mean scores of the sensorial attributes (appearance and color, consistency, odor, taste and overall acceptability) for samples given by the panelists were presented in Table $\mathrm{V}$. The sensory response to the samples demonstrated that the use of probiotic culture combination positively influenced the overall sensory characteristics. The panel found significant differences $(P<0.01)$ for each sample for consistency, odor, taste and overall acceptability, which reflects the advantages of probiotic culture as effective components on the general sensory properties of yogurt. The overall acceptability of yoghurt samples was determined on the basis of the average of the total score obtained for different sensory attributes. The highest overall acceptabilities were obtained for the sample $\mathrm{C}$, and the lowest acceptability scores were for the sample E. Especially, the overall acceptability scores of samples increased during storage of up to 10 days and thereafter decreased for all criteria. This could be associated with development of acidity and decreases in acetaldehyde contents.

TABLE V: CHANGES OF SENSORY PROPERTIES OF SAMPLES DURING STORAGE

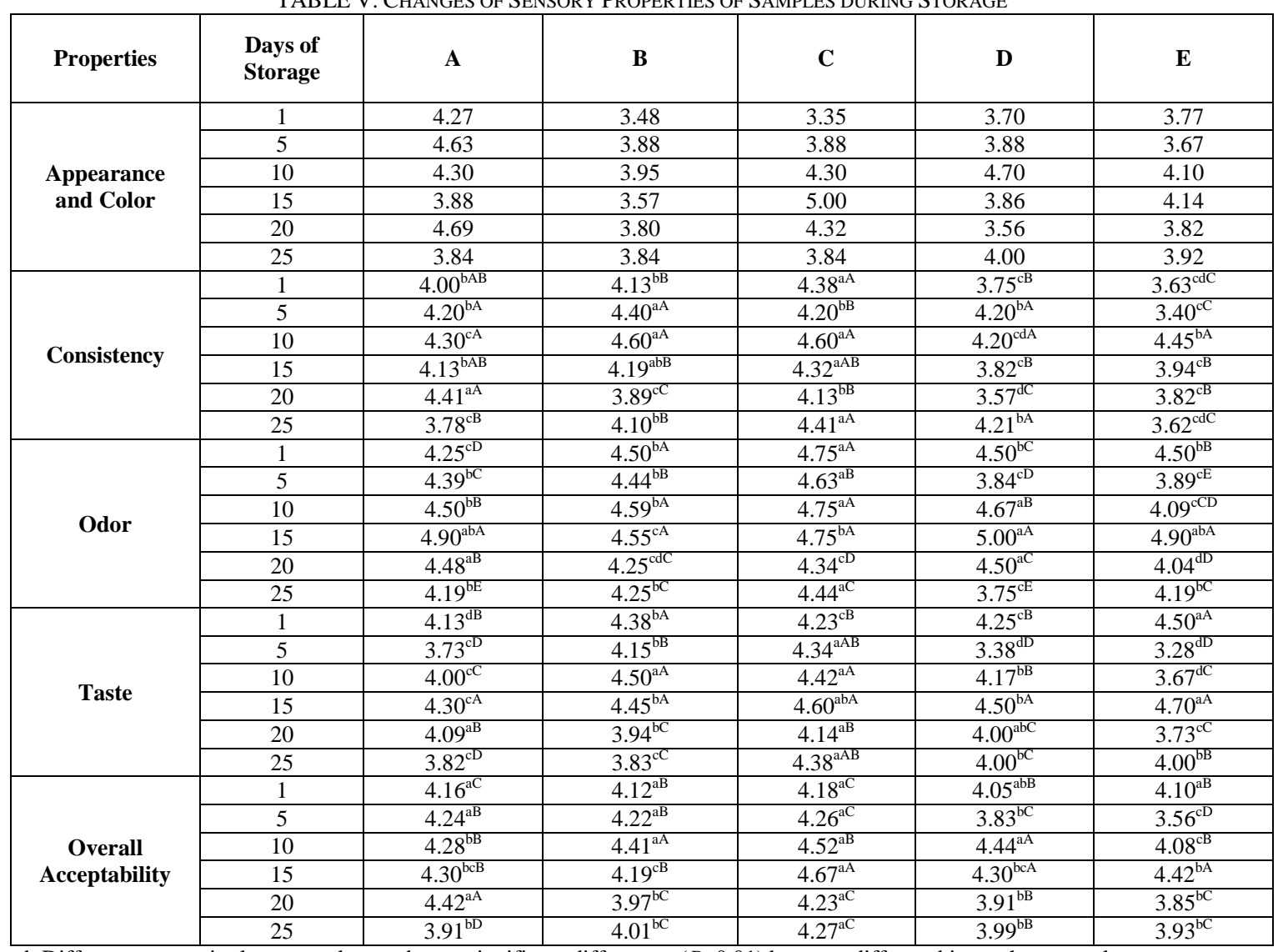

a,b Different superscript lowercase letters denote significant differences $(P<0.01)$ between different bio-yoghurt samples A,B Different superscripts capital letters denote significant differences $(P<0.01)$ between different times of storage 


\section{CONCLUSION}

Different probiotic culture combination and storage time had significant effects on the $\mathrm{pH}$, titratable acidity, syneresis, lactic acid concentration, acetaldehyde contents, viable bacterial counts and sensory characteristics of bio-yogurts. Based on our results, probiotic bacteria used were found to survive throughout storage period and are suitable to provide sufficient number of viable bacteria counts at the time of product consumption. Sample $\mathrm{C}$ received the highest sensory scores from the panelists; however, total sensorial scores for all yoghurts seemed to decrease throughout storage. Further studies are needed to achieve the best physico-chemical and sensory characteristics of the final product to satisfy consumer demands.

\section{REFERENCES}

[1] W. H. Holzapfel and U. Schillinger, "Introduction to pre-and probiotics," Food Res. Int., vol. 35, pp. 109-116, 2002.

[2] M. E. Sanders, "Probiotics: considerations for human health," Nutr. Rev., vol. 61, no. 3, pp. 91-99, 2003.

[3] C. N. Heenan, M. C. Adamsa, R. W. Hoskena, and G. H. Fleet, "Survival and sensory acceptability of probiotic microorganisms in a non-fermented frozen vegetarian dessert," LWT - Food Science and Technology, vol. 37, pp. 461-466, 2004.

[4] D. Commane, R. Hughes, C. Shortt, and I. Rowland, "The potential mechanisms involved in the anti-cangerogenic action of probiotics," Mutat. Res., vol. 591, pp. 276-289, 2005.

[5] D. Samaržija, M. Tudor, T. Prtilo, I. D. Špehar, Š. Zamberlin, and J. Havranek, "Probiotic bacteria in prevention and treatment of diarrhea," Mljekarstvo, vol. 59, no. 1, 28-32, 2009.

[6] C. S. B. Bogsan, A. C. R. Florence, N. Perina, R. C. Barbuti, T. Navarro- Rodriguez, J. N. Eisig, and M. N. Oliveira, "Probiotics intake and metabolic syndrome: A proposal," Trends Food Sci. Technol., vol. 22, pp. 457-464, 2011.

[7] A. C. R. Florence, R. P. S. Oliveira, R. C. Silva, F. A. S. M. Soares, L. A. Gioielli, and M. N. Oliveira, "Organic milk improves Bifidobacterium lactis counts and bioactive fatty acids contents in fermented milk," LWT - Food Science and Technology, vol. 49, pp. 89-95, 2012.

[8] A. M. P. Gomes, F. X. Malcata, F. A. M. Klaver, and H. J. Grande, "Incorporation of Bifidobacterium sp. strain and Lactobacillus acidophilus strain Ki in cheese products in Netherlands," Milk Dairy J., vol. 49, pp. 71-95, 1995.

[9] S. Rybka and K. Kailasapathy, "The survival of culture bacteria in fresh and freeze-dried yoghurts," Australian Journal of Dairy Technology, vol. 50, pp. 51-57, 1995.

[10] L. Blanchette, D. Roy, G. Be'langer, and S. F. Gauthier, "Production of cottage cheese using dressing fermented by bifidobacteria," J. Dairy Sci., vol. 79, pp. 8-15, 1996.

[11] A. M. P. Gomes and F. X. Malcata, "Development of probiotic cheese manufactured from goat milk: response surface analysis via technological manipulation" J. Dairy Sci., vol. 81, pp. 1492-1507, 1998.

[12] T. Vasiljevic and N. P. Shah, "Probiotics - from Metchnikoff to bioactives," International Dairy Journal, vol. 18, pp. 714-728, 2008.

[13] G. Shafiee, A. M. Mortazavian, M. A. Mohammadifar, M. R. Koushki, A. Mohammadi, and R. Mohammadi, "Combined effects of dry matter content, incubation temperature and final $\mathrm{pH}$ of fermentation on biochemical and microbiological characteristics of probiotic fermented milk," African J. Microbiol. Res., vol. 4, pp. 1265-1274, 2010.

[14] A. Lourens-Hattingh and B. C. Viljoen, "Yogurt as probiotic carrier food," International Dairy Journal, vol. 11, pp. 1-17, 2001.

[15] M. B. Güler-Akin, "The effects of different incubation temperatures on the acetaldehyde content and viable bacteria counts of bio-yogurt made from ewe's milk," International Journal of Dairy Technology, vol. 58, no. 3, pp. 174-179, 2005.

[16] N. Abesinghe, J. Vidanarachchi, and S. Silva, "The effect of arrowroot (Maranta arundinacea) extract on the survival of probiotic bacteria in set yoghurt," International Journal of Scientific and Research Publications, vol. 2, no. 5, pp. 1-4, 2012

[17] A. R. Aghajani, R. Pourahmad, and H. R. Mahdavi Adeli, "Evaluation of physicochemical changes and survival of probiotic bacteria in synbiotic yoghurt," Journal of Food Biosciences and Technology, vol. 2, pp. 13-22, 2012
[18] R. I. Dave and N. P. Shah, "Evaluation of Media for Selective Enumeration of Streptococcus thermophilus, Lactobacillus delbrueckii, ssp. bulgaricus, Lactobacillus acidophilus and Bifidobacteria," Journal of Dairy Science, vol. 79, pp. 1529-1536, 1996.

[19] O. N. Donkor, A. Henriksson, T. Vasiljevic, and N. P. Shah, "Effect of acidification on the activity of probiotics in yoghurt during cold storage," International Dairy Journal, vol. 16, pp.1181-1189, 2006.

[20] N. Tharmaraj and N. P. Shah, "Selective enumeration of Lactobacillus delbrueckii ssp. bulgaricus, Streptococcus thermophilus, Lactobacillus acidophilus, Bifidobacteria, Lactobacillus casei, Lactobacillus rhamnosus and Propionibacteria," Journal of Dairy Science, vol. 86, pp. 2288-2296, 2003.

[21] C. G. Vinderola and J. A. Reinheimer, "Culture media for the enumeration of Bifidobacterium bifidum and Lactobacillus acidophilus in the presence of yoghurt bacteria," International Dairy Journal, vol. 9, pp. 497-505, 1999.

[22] L. Lapierre, P. Undeland, and L. J. Cox, "Lithium chloride-sodium propionate agar for the enumeration of Bifidobacteria in fermented dairy products," Journal of Dairy Science, vol. 75, pp. 1192-1196, 1992

[23] M. J. Zimbro and D. A. Power, "Difco \& BBL Manual," Manual of Microbiological Culture Media, pp. 205-206, 2003.

[24] A.O.A.C, Official Methods of Analysis of AOAC International, 16th ed. 481. North Fredrick Avenue Gaithersburg, Maryland, USA. 2005

[25] A.O.A.C., Official methods of analysis of AOAC International, 17th ed., Arling, VA, USA: AOAC International, 2000.

[26] M. Atamer and E. Sezgin, "Effect of increasing of dry matter on physical properties of coagulum in yoghurts," Glda (Turkish), vol.11, pp. 327-331, 1986

[27] K. Steinsholt and H. E. Calbert, "Rapid colorimetric methods for determination of lactic acid in milk products," Milchwissenschaft, vol. 31, no. 1, pp. 7-10, 1960.

[28] G. J. Lees and G. R. Jago, "Methods for the estimation of acetaldehyde in cultured dairy products," Australian Journal of Dairy Technology, vol. 71, pp. 3203-3213, 1969.

[29] R. I. Dave and N. P. Shah, "Viability of yogurt and probiotic bacteria in yogurts made from commercial starter cultures," International Dairy Journal, vol. 7, pp. 31-41, 1997.

[30] C. G. Vinderola, N. Bailo, and J. A. Reinheimer, "Survival of probiotic microflora in Argentinian yoghurts during refrigerated storage," Food Res. Int. vol. 33, pp. 97-102, 2000.

[31] W. Gustaw, M. Kordowska-Wiater, and J. Kozioł, "The influence of selected prebiotics on the growth of lactic acid bacteria for bio-yoghurt production," Acta Sci. Pol., Technol. Aliment., vol. 10, pp. 455-466, 2011.

[32] G. Singh, I. P. S. Kapoor, and P. Singh, "Effect of volatile oil and oleoresin of anise on the shelf life of yoghurt," J. Food Process. Preserv. vol. 35, pp. 778-783, 2011.

[33] B. Ozer, A. Kirmaci, S. Oztekin, A. A. Hayaloglu, and M. Atamer, "Incorporation of microbial transglutaminase into non - fat yoghurt production," International Dairy Journal, vol. 17, pp. 199 -207, 2007.

[34] M. T. N. Ranathunga and R. Rathnayaka, "Comparison of physicochemical and sensory properties of probiotic and natural yoghurt," Journal of Biological and Food Science Research, vol. 2, pp. 1-6, 2013.

[35] R. Mahmoudi, P. Zare, P. Hassanzadeh, and S. Nosratpour, "Effect of Teucrium Polium essential oil on the physicochemical and sensory properties of probiotic yoghurt," Journal of Food Processing and Preservation, pp.1-9, 2012.

[36] N. Vahcic and M. Hruskar, "Slovenian fermented milk with probiotics," Zootehnika, vol. 76, pp. 41-46, 2000.

[37] M. B. Guler-Akin and M. S. Akin, "Effects of cysteine and different incubation temperatures on the microflora, chemical composition and sensory characteristics of bio-yogurt made from goat's milk," Food Chemistry, vol. 100, pp. 788-793, 2007.

[38] D. Ozer, S. Akin, and B. Ozer, "Effect of inulin and lactulose on survival of Lactobacillus acidophilus LA-5 and Bifidobacterium bifidum BB-02 in acidophilus-bifidus yoghurt," Food Sci Tech Int., vol. 11, pp. 19-24, 2005.

[39] P. S. Panesar and C. Shinde, "Effect of storage on syneresis, pH, Lactobacillus acidophilus count, Bifidobacterium bifidum count of Aloe vera fortified probiotic yoghurt," Current Research in Dairy Sciences, vol. 4, pp. 17-23, 2012.

[40] A. Y. Tamime, V. E. Marshall, and R. K. Robinson, "Microbiological aspects of milks fermented by Bifidobacteria," Journal of Dairy Research, vol. 62, pp. 151-187, 1995.

[41] P. F. Fox, P. McSweeney, T. M. Cogan, and T. P. Guinee, Fundamentals of cheese science, 1st Ed. Springer, New York, 2000.

[42] M. Sady, T. Grega, D. Najgebauer, J. Domagala, and B. Faber, "Nutritive value of Bio-yoghurts with amaranthus seeds and oat grains 
additives," Biotechnology in Animal Husbandry, vol. 21, pp. 245-249, 2005.

[43] P. Bano, M. Abdullah, M. Nadeem, M. E. Babar, and G. A. Khan, "Preparation of functional yoghurt from sheep and goat milk blends," Pak. J. Agri. Sci., vol. 48, pp. 211-215, 2011.

[44] W. Routray and H. N. Mishra, "Scientific and technical aspects of yogurt aroma and taste: A Review," Comprehensive Reviews in Food Science and Food Safety, vol. 10, pp. 208-220, 2011.

[45] G. Bonczar, M. Wszolek, and A. Siuta, "The effects of certain factors on the properties of yogurt made from ewe's milk," Food Chemistry, vol. 79, pp. 85-91, 2002.

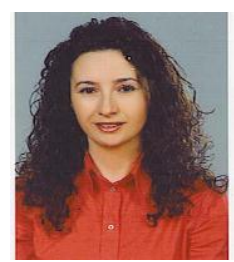

Lutfiye Yilmaz-Ersan is an assistant professor of Department of Food Engineering at the Uludag University, Bursa, Turkey. More recently, she has worked dairy and dairy products. From 2007 to 2008 (14 months) she worked at University of Nebraska-Lincoln USA, Department of Food Science and Technology as a visiting scientist. Her probiotics and prebiotics. areas of interest include dairy and dairy products, 